UDC 821.161.1 - Baltrush.21

DOI https://doi.org/10.32838/2710-4656/2021.2-2/28

Shcherbina $\boldsymbol{V} . \boldsymbol{V}$.

National Academy of the National Guard of Ukraine

ORCID ID: 0000-0002-2717-3855

\title{
THE COLOUR PARADIGM AS A FEATURE OF YURGIS BALTRUSHAITIS' POETIC WORLD IN THE CONTEXT OF RUSSIAN SYMBOLIST POETRY
}

The article is devoted to the analysis of the colour paradigm in Yurgis Baltrushaitis' artistic world. Russian symbolists contributed to the world literature both unique system of poetic images and the original colour paradigm. The perception of colours differs in the poems of representatives of the older and younger symbolist poets and reflects their philosophic and aesthetic views.

The purpose of the article is is to reveal the features of colour paradigm in Yurgis Baltrushaitis' artistic world, to outline the similarity and difference in the use of colour images in Y. Baltrushaitis' poetic works in the context of the Russian Symbolists of older and younger generations. According to poet's philosophic views, human life consists of two repeated processes - ascend and descent. These processes are challenging but they can cause change and innovation. The same colour images accompany the lyrical character and contribute to developing the theme of eternal motion.

The blue colour appears to be one of the most frequently used in Y. Baltrushaitis 'colour paradigm. The image of blueness is characterized with richness of contents, mobility and diversity. The analysis of different periods of Baltrushaitis creative activity indicates the way the image of blueness and poet's perception of the blue colour changes. The image of blueness develops in a circular way. In the early poems the poet uses the images blueness-truth, blueness-eternity, blueness-youth, blueness-constancy. In later poems the image blueness-truth also seems to be productive but it acquires deeper philosophic implication.

The use of the azure colour is influenced by poet 's specific outlook and religious tradition. The image of azure appears to be mobile and fluid. In early Baltrushaitis'poetry azure is associated with joyful youth, in later poems the azure is the attribute of the unearthly world and the characteristic of creativity act.

It is shown that in early Baltrushaitis "poems the white colour is used for creating images of nature. In late Baltrushaitis 'the whiteness is associated with the apocalyptical motifs and the theme of expecting the Messiah coming. The image of white corn in poet s artistic world symbolizes the return to the primary source and the start of a new life cycle.

Key words: colour paradigm, image, lyrics, artistic world.

Formulation of the problem. Russian Symbolists contributed to the world literature the unique system of literary images, the specific emotional colouring as well as original colour paradigm that revealed symbolists` aesthetic views, their conception of colour and ideas of colour system since the early Medieval times till the beginning of the XX century.

The issues, connected with colour perception, can be found in theoretical works of many famous scholars. The philosophers, who belonged to different historical periods, created their own colour system, trying to define the dominating colours. Plato, the great philosopher of Ancient Greece, expressed his attitude to the problem mentioned in his famous Colour Theory, in which golden, white and purple were considered to be dominating ones. "In the early Medieval Europe the red colour seemed to be the most preferable. The transition from the red colour to the blue colour appeared to be a very slow process. During the late Medieval period the white and blue colours were on the top of certain hierarchy and the red colour was in the middle. The yellow and black (the colour of purgatory) seemed to be at the end of the scale of values", - points out A. Khanzen-Lyove [16, c. 471].

Colour symbols were described and analyzed in the works of M. Enkhart and Y. Byome. The poet and researcher V. Solovyov, whose idealistic philosophy affected the second generation of the Russian symbolists, devoted his work "Beauty in Nature" to the problem of basing light and colour for symbolism. In symbolist poetry colour was regarded as the expression of poetic view of the world. With the help of colour concept representatives of new 
art tried to widen artistic outlook of literature, to elevate it over everyday life as well as to aim colour usage at solving eternal questions of human being. New attitude to colour became the important feature of symbolist poetics. The founders of the Russian Symbolism considered colour to be the means of the world transfiguration and found in it the highest aesthetic value. The Russian researcher M. Gasparov points out: "Symbolism works out absolutely new words-signals as well as unique expressive means which make the new poetry recognizable. Moreover, every poet works out own image system based upon unrepeatable connections between words. Every word obtains additional meaning and becomes expressive. Every colour gets a number of additional meanings and becomes a symbol itself" [9, c. 19].

In some aspects the Russian Symbolism was strongly affected by the French Impressionism, "which claimed for widening the artistic impressionability and contributes to forming symbolist imagery on subjective basis" [9, c. 23]. The poetry of the Russian Silver Age was aimed at creating special mood and mesmerizing readers. The colour was used to focus on artist's subjective sensations and changeable feelings and keep them. It was important that the artist got down to some colour equivalent and created his own artistic world as well as colour paradigm.

Literature review. The first works, devoted to the analysis of colour images were created by the representatives of the new poetic school. Valery Bryusov, one of the founders of the Russian Symbolism, devoted his articles to the theoretical aspects of a new artistic and literary movement. V. Bryusov claimed the influence of French impressionist art on the Russian symbolist poetry. The representative of older generation of Russian Symbolists wrote, that "natural colours in their ordinary understanding cannot be used in symbolist poetry. The true artist shouldn't copy the existing world, because his task is to create his own one with the help of impressionist expressive means which are necessary for turning an idea into a poetic image" [8, c. 27].

Konstantin Balmont, another representative of older symbolist generation, devoted his theoretical works to the problem of connection between sound and visual images. Such connection became the basis of Balmont's poetic world. It helped him to express the spirit of life acelaration, one of the most important features of his poetry. Balmont's artistic world is full of bright and sophisticated synesthetic images, which the poet subordinates to the direction of lyrical plot.

Alexander Blok, the representative of younger symbolist generation, emphasized the significance of visual poetic images. In his famous article "Colours and Words" [6] the poet explained why literature had to learn from painting: "The art of colours and lines gives the opportunity to remember about closeness to the nature and prevents the writer from using schemes, which can destroy the poetic mood. Painting teaches people to look as well as to see. These things are quite different and they seldom coincide" [6, c. 72]. A. Blok considered colours, an artist used, to be more exact and truthful than words. The poet wrote a lot about the way art developed and the targets it set. In Blok's opinion, only the true artist could understand the world as well as help both the readers and viewers to comprehend the essence of things. The ability to see the beauty of colours and to demonstrate it in poetry seemed to be the important characteristic of a true poet. The effect of light and colour was regarded as some liberating force that was enough to express the originality of the idea in poetic world.

Yurgis Baltrushaitis was always interested in the concept of artistic synthesis. The poet was sure that true creative activity could overcome the borderlines between genres of art. Baltrushaitis was a close friend of A. Skryabin, the outstanding Russian composer, who tried to express philosophic ideas with the help of music. The poet did a lot to popularize the creative works of his compatriot M. Chyurlyonis, who aimed at combining music and colour. Analyzing the poet's artistic world, the Lithuanian researcher V.Dauyetite [10] describes friendship and cooperation of her two famous compatriots. The scholar pays attention to the fact of strong influence, made by M. Chyurlyonis paintings on Baltrushaitis' poetic world.

Another Lithuanian researcher B. Merzhvenskite [13] takes into consideration the specific role of the red colour in Baltrushaitis ' poetry. The scholar analyses the concept of creative personality in symbolist poetry and compares functions of red colour in Alexander Blok's and Baltrushaitis 'poems.

The Austrian researcher A. Khanzen-Lyove [16] classified and systemized the main motives and themes of the Russian Symbolist poetry. The scholar pays special attention to the apocalyptical motives and biblical images, based upon the use of white colour in Baltrushaitis` poetic world.

The researcher B. Tukh analyzed the functions of white colour "as a characteristic of Nordic strength, typical of Baltrushaitis' poetics" [15, c. 92]. In B.Tukh`s opinion, Baltrushaitis belonged to so-called northern modern, the poetic trend, imbued with the mystic spirit and aspiration for space and light.

The total number of the works, devoted to Baltrushaitis' poetics doesn't correspond either 
the artistic contents of his poems or the contribution he made into the literary process. Baltrushaitis' artistic world still remains the least studied aspect of his creative activity. The lack of holistic approach to the analysis of Baltrushaitis poetics, in general, and colour paradigm, in particular, makes our research actual.

The purpose of the article is to reveal the features of colour paradigm in Yurgis Baltrushaitis' artistic world, to outline the similarity and difference in the use of colour images in Y. Baltrushaitis' poetic works in the context of the Russian Symbolists of older and younger generations. The analysis of colour paradigm in Y.Baltrushaitis' poems will give the opportunity to evaluate the original poetic atmosphere and musicality of figurative word as well as to define more exactly the poet's position both in the history of the Russian Symbolism and in the 20-th Century Literature.

Outline of the basic material. Yurgis Baltrushaitis' artistic world is full of reflections on human life and man's position in the earthly being. During his artistic evolution the poet created the similar images, revealed the same themes and solved the same problems. The repeated main images, the certain feelings and emotions can be found in the poems belonging to different periods of Baltrushaitis' creative activity. The lyrical character in poet's artistic world is always on his way to the heavenly world of beauty, light and harmony which seemed to be remote and unattainable rising somewhere very far behind the ocean of doubts and disbelief. The way to this harmonious world can be found with the help of signs and symbols. The colour is seen to be one of such symbols. According to poet's philosophic views, human life consists of two repeated processes - ascend and descent. These processes are challenging but they can cause change and innovation. The same colour images accompany the lyrical character and contribute to developing the theme of eternal motion. The repeated images appear to unite all the poems into the whole text with the common plot and the same lyrical character, who suffers from hardships and trials and consequently grows and develops mentally and spiritually. Let's consider the role of colour images in Baltrushaitis' poetics and define functions of different colours in poet's artistic world in the context of Russian Symbolist poetry as well as the tendencies of European Symbolist movement.

According to many researchers' points of view, European culture has remained the culture of the blue and dark blue colours since the late Medieval times. The blue colour appears to be one of the most frequently used in Y. Baltrushaitis' colour paradigm. The image of blueness is characterized with richness of contents, mobility and diversity. In early poems Baltrushaitis identifies blueness with eternity which defeats vanity of earthly life: "V yunom serdtse - v znoynom nebe - / Tish - siyanye - sineva .../ Slavsya, v zhisni, kazdy zhrebiy! / Zvonche gordyye slova!" ("Polden") [40]. In the poem "Polden" the poet identifies the human soul with the outer world. The lyrical character is young and cheerful. There is everything in his soul that can be found in the sky. Life seemed to be wonderful and endless. He believes that any troubles he faces are temporary and surmountable. "Vikhr promchitsya 1, lug yerosha.../ Mir romashka ty pchela, / Pust tvoya zemnaya nosha / Budet sladko tyazhela..." ("Polden") $[2$, c.40]. In early Baltrushaitis' poems the concept of human being completeness and harmony is correlated to man's relations with the nature. There is no human being in the earthly world but the nature is ready to accept him and open all its mysteries. The nature is shown in its beauty and greatness. The idea of possible unity of man and nature can be heard in many poet's early works.

In the poem "Sineva" the blueness is identified with eternity and constancy. Trying to worship nature, the poet called people to reflect on nature and carefully delve into its secrets. "Poystriy mir klonya $\mathrm{k}$ pokoyu / Mysli, podvigi, slova - / Pravit doleyu lyudskoyu / Tselnost, vechnost, sineva" ("Sineva") [2, c.147]. In poet's opinion human being has to look for spiritual connection both with another human being and with every smallest component of nature in which the reflection of eternity can be seen.

The image blueness-eternity can be found in artistic world of other symbolists. In the poem "Na Bulvare" V.Bryusov, the representative of the older generation of the Russian symbolists, also identifies blueness with eternity and constancy: "Zdravstvuy, prezhniy, svezhiy veter, / Zdravstvuy, noviy, svetliy Melor, / Sosny, temniye po sklonam, / Pyatna yarkiye listvy, / I nad beregom zelyonom / Blagost vechnoy sinevy!" ("Na Melore") [7, c. 454]. In later Bryusov`s poems eternity is associated with light blue and azure colours.

The image of blueness can be seen as the guarantee of eternal life. The lyrical character is eager to become the integral part of nature. In Baltrushaitis' poem "Krug Vekovechniy" man is viewed as a philosopher of nature, careful, wise and ready to peer into each blade of grass. The blue colour is associated with summer, which in Baltrushaitis' collection of poems "Earthly Steps"(“Zemnye stupeni”) symbolizes joyful youth, the happiest period in human life. "Blizitsya noch k rassvetu / Yasen shelest listvy / Stroitsya 
stebel k tsvety, / Tsvet lish zhdet sinevy / Lyetsya, kak plamya v vody, / Siniy radostniy den - / Kholit zemnye vskhody / V polden svetlaya ten" ("Krug Vekovechniy") [2, c. 106]. The world is depicted in some unity of man and nature. The blue colour is also seen as the symbol of immensity of space, the boundlessness of earthly vastness.

The image of blue vastness is frequently used in A. Blok`s poetic world. In the poem "Yarkim Solntsem, Siney Daliyu..." the blue vastness appeared to be mysterious and unattainable: "Yarkim solntsem, siney dalyu / V letniy polden lyubovatsya - / Neponyatnoyu pechalyu / Dali solnechnoy terzatsya, / Kto poymet, izmerit okom, / Chto za etoy siney dalyu? / Lish mechtanye o dalekom / S neponyatnoyu pechalyu" [5, c. 35]. The blue vastness attracts the lyrical character and captivates him. He is unconsciously longing to reach it. Man realizes that it is impossible to reveal the mysteries of blue vastness, but he keeps on trying and hopes for obtaining harmony with the nature and surrounding world.

In K. Balmont's artistic world the image of blue vastness appeared to be productive. The poet was eager to depict both the most significant events in the world history and the most outstanding historical figures. Balmont was the first to create a new lyrical genre - the poetic portrait of a certain place or a certain celebrity. The poet, who travelled a lot, created the bright images of various countries, great cities, hallmarks and places of interest. The symbolic portraits of political and military leaders, genius of culture were admired by the readers. The researcher L. Kolobayeva points out: "Balmont's lyrical character is like a spirit flying among various time periods in boundless space. This space doesn't seem to be abstract, it involves the time of historic cultures. In poetic images of famous artists, poets, playwrights Balmont wants to capture the unique achievement of human personality as well as the image of various culture of different times with their national colouring and universal significance" [12, c. 79].

The image of blue vastness in the poem "Slavyanskoye Drevo" is connected with the theme of Slavic origin: "Kornyami gnezditsya gluboko v zemle / I v bessmertnom podzemnom ogne / Vershinoy voskhodit $\mathrm{k}$ vysokoy skale, / Zelyonyye vetvi uvodit shiroko v bezmernuyu dal" ("Slavyanskoye Drevo") [3, c. 127]. Balmont is pondering over the long and glorious history of Slavic peoples. In poet's opinion, they faced hardships and sufferings and always demonstrated strong will and courage. The image of blue vastness is associated with endless prospects awaiting for them in their further history.
In Baltrushaitis' collection of poems "Gornaya Tropa" the same lyrical character appears to be more independent and mature. Ascending earthly steps man stopped being the passive observer and helpless admirer of the nature. The lyrical character reached the golden peak of his life and time started contracting and made him appreciate each moment of his life. The changes in lyrical character's spiritual sphere contribute to the change of other images in general, and colour images, in particular. The blue colour acquires deeper and more philosophical sense: "Tyanutsya vetvi k oblasti gorney, / K zvyozdam v bestrepetnoy mgle... / Skryty gluboko tyomnyye korni / Taynoyu setyu, v zemle, / Ne potomu li v poru nedoli / Svetit dushe sineva - / V svete bespechnom, ne ottogo li / Sumrachno shepchet listva" ("Derevo") [2, c. 119].

The poet identifies the blueness with the highest truth which is both inside the person and beyond him. The image of the tree in the poem appears to be significant. The lyrical character seeks for wisdom as much as the tree seeks for the enormous blue sky. The blueness indicates the way and fills the lyrical character's soul with quiet confidence and serenity. Man in Baltrushaitis' artistic world is always in motion and the moments of spiritual peace seem to be rare. The more man admires and loves nature and earthly world, the more worried and anxious about shortness of human life he becomes. This idea seems to be especially painful when the character compares human fate with the constantly reviving and innovating nature. According to the lyrical plot of the book "Gornaya Tropa" the short and happy period of ascent is followed by the descent, another period of lyrical character's life, full of sufferings and trials. The perception of nature as well as the blue colour changes again. The lyrical character is getting older and wiser. The blue colour is more often associated with cold, indifferent and hostile force: "I v sineve, gde merknet tsvet, / Gde ni luny, ni solntsa net, / U zybkoy grani smertnykh dney, / Za rubezhom nochnykh teney / Uvidish ty zapretnyy kray, / Gde zreyet zvezdnyy urozhay" ("Prizyv") $[2$, c. 113]. Nature is the only genuine reality. Nature can be different: kind and sympathetic, hostile and threatening but it remains remote and unattainable with all its magic and mysteries.

The changes in perception of blue colour correspond to the stages of lyrical character spiritual growth. In the poems representing later period of creative activity Baltrushaitis uses the blue colour to emphasize person's loneliness and emptiness. The poet thinks over human life spent on fruitless 
seeking for harmony and completeness of earthly being. In the poem "Osenyu" the lyrical character feels that his hopes for reaching unearthly world are broken. The image of blue colour in this poetic context is associated with alien world that can bring only cold gloom and darkness. The gorgeous blueness, the lyrical character used to admire in the youth, faded away and darkled: "Sinyeyut dali bez priveta... / Ugryum zaglokhshiy krug zemli... / I, kak pechalnaya primeta, / Melkayut s krikom zhuravli... / Plyvyot ikh zybkiy treugolnik, / Slivayas s blednoy sinevoy.../ Molis, toskuyushiy nevolnik, / Svobode doli kochevoy!" ("Osenyu”) [2, c. 169].

In Blok's poems the blue colour can be associated with personal disappointment and the loss of love. In the poem "Pomnish li Gorod Trevozhniy..." the blue colour appears to be the symbol of hostile urban surrounding which deprived the lyrical character of his love. "Nasha lyubov obmanulas, / Ili stezya uvlekla, / Tolko vo mne shevelnulas / Sinyaya goroda mgla.../ Pomnish li gorod trevozhniy, / Sinyuyu dymku vdali?" [5, c. 26]. The poet depicts the tragic moment in lyrical character's life. The blue colour is used to indicate man's hard state of mind. The image of blue vastness is changed by blue haze, the symbol of disillusionment.

In the poem "Put k Sineve" Baltrushaitis traces all the stages of lyrical character's spiritual growth. In the same poetic context the hero appears to be carefree and young, then mature and full of premonitions. The blue abyss of heaven always attracted the lyrical character and promised him reaching the harmony. The hopes didn't justify, illusions disappeared but man did his best to remain strong-willed and stoical. He can put up with bitter truth and worship wise and magnificent nature: "I v mertvom prostore, / Nad seroy dorogoy, / Gde glukho sedeyet trava / Bezmolvno I strogo, / Kak sineye more, / Raskryla svoy mir sineva" ("Put k Sineve") [2, c. 139].

The analysis of different periods of Baltrushaitis` creative activity indicates the way the image of blueness and poet's perception of the blue colour changes. The image of blueness develops in a circular way. In the early poems the poet uses the images blueness-truth, blueness-eternity, blueness-youth, blueness-constancy. In later poems the image blueness-truth also seems to be productive but it acquires deeper philosophic implication. The paradigm, built on the image of blueness, starts with the image blueness-truth and finishes with it, but the image content changes noticeably. The truth captivates the lyrical character but acquires the shade of cold aloofness.
Russian Symbolists often turned to literary symbolic, connected with certain mythological or religious tradition. The azure colour is seen to be one of such symbols. "Azure is the most dematerialized out of meaningful colours on the border between extraterrestrial space and airy atmosphere of the Earth. The symbolic function of the azure can be compared with the function of background blue colour, which in the Medieval painting served for setting off the religious images", - writes A. Khanzen-Lyove [16, c. 425]. The image of azure and the azure colour appear to be productive in Baltrushaitis' artistic world. Azure in poet's lyrics is the colour of the sea, the sky as well as the symbol of the best period of human life. "Skudeyet v nebe svetlaya lazur, / Proshla volna! / Lish v temnom serdtse otzvuk dalnikh bur / Ne znayet sna" ("Vecherniy Dym") [2, c. 93]. The azure in Baltrushaitis' poems is not viewed as something still and motionless. It appears to be changeable and movable.

In A. Bely's poetry the azure moves, changes colour and lives its own life. In the poem "Vozvrat" the image of azure is associated with the flow of time: "Nad golovoy - polet stoletiy bystriy. / Teki, lazur, k moyey peshchere gornoy. / Lazur, temneya, rassypayet iskry" ("Vozvrat") [4, c. 60].

In early A.Blok's artistic world azure is the colour of mysterious unearthly world. It appears to be the symbol of something which is unattainable and seems to be beyond man's understanding: "Vnochneproglyadnuyu, burnuyu/Vdrugraspakhnulos okno.../ Mimo videnye lazurnoye! / Serdtse szhimayet toskoy" (Shli my stezeyu lazurnoyu...") [5, c. 38]. In his famous poetic cycle "Stikhi o Prekrasnoy Dame" ("The Poems about the Fair Lady") A. Block created the image of gold in the azure (zoloto $\mathrm{v}$ lazuri). This unique image occupies the central place in this cycle. The image is connected with the V. Solovyov's poem "Three Dates", whose heroine appeared before the lyrical character on the background of golden azure.

The researcher N. Sokolova points out that "the word azure appears to be the sign of the highest sense. It reflects the absolute harmonious ideal of "unearthly world", typical for the Fair Lady. This world seems to be unattainable and incomprehensible" $[14$, c. 87]. The heroin of Blok's cycle gradually becomes light and radiant. The lyrical character is longing for ideal, who inspires melancholy and hope for realizing the dream and reaching the heavenly world. "No vnezapno nega schastia / Zamenila rokot bur... / Vmesto shumnogo nenestia - / Nado mnoy tvoya lazur!" ("Nabrosok") [5, c. 389].

The image gold in the azure in A. Bely's artistic world also has the complicated origin. The researcher 
N. Kozhevnikova [11, c. 45] identifies three sources of this image. The first one is the ancient Greek myth about the Golden Fleece. V. Slovyov`s poetry is considered to be the second source. In researcher's opinion, Bible is the third source of the image. Golden azure in A. Bely's poem "Utro" symbolizes the unearthly world, which seems to be obscure and out of reach. The lyrical character used to be ill, but morning brings him recovery and return from the mysterious almost mystical sphere which he visited during his illness: "Tam - v purpure zori. / Tam - buri i v purpure buri. / Voskres ya - glyadite! Voskres./ Moygrob uplyvayet / Tuda - v zolotyye lazuri..." ("Utro") [4, c. 97].

The image of azure seems to be quite different in K. Balmont's lyrics. In the poem "Kinzhalnyye Slova" the azure is the symbol of calmness and fruitless dreams. The azure surrounds the lyrical character, covers him and prevents him from being active, from having trials and hardships he is eager to face: "Ya khochu porvat lazur / Uspokoyennykh mechtaniy, / Ya khochu goryashchikh zdaniy, / Ya khochu krichashchikh bur!" ("Kinzhalnyye Slova") [3, c. 35].

For V. Bryusov, another representative of the older symbolist generation, the azure shine appears to be the attribute of the Renaissance. In the poem "Fonariki" the poet associates the certain historical epoch and the country, flourishing at that time with the definite colour. Assyria gets the red colour, Egypt appeares to be yellow. Ancient Rome is associated with the white colour. Italy and the epoch of Renaissance are depicted in golden splendor and azure shine: "Vek Dante - blesk tainstvennyy, zloveshcheye zolotoy.../ Lazurnoye siyaniye, o Leonardo, - tvoy" ("Fonariki") [7, c. 435].

The researcher V. Alfonsov points out, that "for many symbolist poets Leonardo 's creative activity was especially attractive" [1, c. 67]. The images connected with the Renaissance can be found in lyrics of A. Blok, V. Ivanov, V. Bryusov and many other representatives of symbolist poetry. The art of painting often proved to be prophetic as it revealed the truth and confirmed poets' premonitions and anticipations. In Leonardo da Vinci's art the Russian symbolist poets found the features of their contemporary. V. Brysov chooses the azure colour to characterize Leonardo's epoch as the image of azure, in A. Khanzen-Lyove opinion, is associated "with mystical concept of pouring light or the stream of rays from visionary gap, revealing the cosmic sea" [16, c. 427]. The famous figures of the Renaissance were trying to solve the mystery of pouring light and make the azure shine on their canvases and highlight the beauty of women`s faces full of nobility and innocence.

In Baltrushaitis` artistic world there are neither ancient and exotic images nor symbols, connected with the Renaissance epoch. In early poems the image of the azure is associated with the biblical motifs and images: «No rog, zovushchiy tainu k yavi, / Vsyo zvonche pel, / I drognul mir v lazurnoy slave, / I den vskipel" ("Drevneye Skazaniye") [2, c. 103]. In this poetic context the author expresses his vision of origin of the world. The image of the azure is associated with the miracle of appearing life on the Earth. In his lyrics Baltrushaitis is trying to answer the major ideological questions. The world doesn't have final outlines. All the objects and phenomena are born anew every day.

In late poems the image of azure glory becomes frequent in Baltrushaitis' lyrics. In the poem "Razdumye" the poet emphasizes the crucial role of the Creator in everything what happens in the earthly world: "I vot, sred vsekh razlichiy yavi, / Chto dlitsya vek, chto dyshit mig, / V pyli zemnoy v lazurnoy slave, / Ya vizhu tot zhe znak I lik" ("Razdumye") [2, c. 171]. The image of azure expresses Baltrushaitis' attitude to the concept of time and reflects his perception of eternity. The image of daytime in poet's lyrics is associated with the best period of man's life:"Blazhen, chey den lazurnym krugom/Oblyok polya, venchal proctor .../ Blazhen, chey put prokhodit lugom, / Gde pyostriy tsvet vstrechayet vzor..." ("Beati Possidentes") [2, c. 144].

In Baltrushaitis`artistic world the azure colour can also symbolize the divine wisdom, that fills man's life with light and harmony, helps man to pass through sufferings and sorrows, to overcome troubles and severities without falling into despair: " $\mathrm{Za}$ rabstvo, slyozy i istomu / Chas vozdoyanya brezzhit nam - / Yest glub lazuri dnyu lyudskomu, / I zvyozdy yest zemnym nocham!" ("Razdumye") [2, c. 200].

The image of the azure appears to be productive in Baltrushaitis ' poems devoted to the theme of creative personality and the concept of true artist. In the poem "Pamyati Skryabina" the azure symbolizes the eternal truth which can be comprehended only by a true artist. For Baltrushaitis the great Russian composer A.Skryabin seems to be the prophet, the genius, who in his great music managed to avoid death. In poet's opinion Skryabin's music contains divine unearthly intonations aimed to the whole universe: "On s name byl sred trudnoy teni utra, / On nam predryek lazur I glub poludnya, / On budet nam vecherneyu zvezdoy" ("Pamyati A.N. Skryabina") [2, c. 266]. In Baltrushaitis' artistic world the image of the azure 
proves to be fluid and changeable. It develops in accordance with lyrical character's spiritual growth.

The white colour occupies significant place in Baltrushaitis' lyrics. The analysis of poet's artistic world shows that white absorbs all the colours, dissolve and transform them and as a result stops to be the colour and turns into the symbol, some quality or feature of the unearthly world. "Gudur v sadu iz blednukh, nezhnykh, / Iz lunnykh liliy, i sred nikh / Pred neyu, v rizakh belosnezhnykh, / Yee toskuyushchiy zhenikh" ("Lunnaya Sonata") [2, c. 75]. In this poetic context white seems to be the symbol of mysterious and scary world of shadows. The dead hurting whiteness occupies all the space. The repeated girl's name emphasizes the lyrical heroin's loneliness and intensifies the feeling of anxious restlessness. In the poem the apocalyptical motifs can be distinctly heard.

White seems to be productive in many symbolist poets' creative activity. N.Sokolova points out that "in A. Blok's poetry white often symbolizes the underworld, something unearthly, mysterious and all-powerful" [89]. "Neotvyazniy stoit na doroge, / Beliy - smotrit v moroznuyu dal" [14, c. 145].

In K. Balmont's artistic world white is associated with the idea of innocence and purity. The lyrical character of K. Balmont's poem "Snezhinka" sincerely admires the lightness, dazzling purity and beauty of a tiny snowflake: "Svetlo-pushistaya, / Snezhinka belaya, / Kakaya chistaya, kakaya smelaya! / V luchakh blistayushchikh / Skolzit, umelaya, / Sred khlopyev tayushchikh / Sokhranno-belaya" ("Snezhinka") [3, c. 78].

In early poems Baltrushaitis also uses the white colour for creating images of nature. In the poem "Vecher v Gorakh" white is the colour of the mountain peaks, which are far from human hustle and unapproachable for man. Mountain peaks rise high into the sky, where the other world, strange and cold, is hidden. White is the symbol of this world: "V sonnom tsarstve vechnykh ldov ... / Belykh zamkov, gorodov... / U vorot ikh, stroyas v ryad, / Strazhi belyye stoyat" ("Vecher v Gorakh") [2, c. 107]. In this poetic context white is associated with eternal peace and is used for depicting enduring magnificence of mountains in their splendid steadiness.

In late Baltrushaitis' lyrics the white colour is used in the poems in which the apocalyptical motifs can be distinctly heard. In the poem "Marcia Eroica" the author opens the amazing picture of snowstorm. The theme of the poem is expecting the Messiah coming. The epigraph before the poem is taken from the Catholic hymn and contains the reminder about the inevitable Doomsday. The apocalyptical motifs are reflected in the image system of the poem.
The poet depicts White Knight, accompanied by the angel cavalry, fearsome trumpeter, who wakes the sleeping world with the magic sounds of his silver horn and warns that the struggle between the light and evil forces has started. The whiteness covers all the space and soon even the moon looks like a dark spot on the dazzling white background. "V snezhnoy pustyne, sred lunnykh ogney, / Belyye vsadniki gonyat koney.../ Snezhnym tumanom dymyatsya polya, / Belym pozharom obyata zemlya!" [2, c. 90].

The apocalyptical motifs can be also heard in Baltrushaitis" poem "Venchaniye", which was highly appreciated by K. Balmont in his article "Poetry as Magic" ("Poeziya kak Volshebstvo"). The representative of the older symbolist generation emphasized the musicality, specific mood and atmosphere of the poem: "In Baltrushaitis" tune, which seems to be wide and free, there is no tightness of a room, but there is open sunny space, in which love is not the curse, but death appears to be blessing and love" [3, c. 300].

The white colour is the part of the most productive image in Baltrushaitis' lyrics. The image of the white corn can be found in many poems belonging to different periods of creative activity. The white corn is seen to be the condition of life continuity. In the poem "Zimnyaya Doroga" the poet opens before readers the other snowy landscape, which fills the soul with spiritual peace and serenity. The image of white corn gives the lyrical character hope for reaching joy and harmony.

"Den I noch sred snega - / Dva glukhikh zerna, / Dva nemykh pobega / Belogo zerna... / Vskryla v dalyakh Boga / I v grudi lyudskoy / Belaya doroga / Bely svoy pokoy" ("Zimnyaya Doroga") [2, c. 118]. In this poetic context the white colour remains the characteristic of the Higher forces but loses the coldness and hostility towards man. The snow, quietly falling down and white winter road, are associated with the bright pictures of awakening nature and coming spring: "Smutno i bezbolno / Snitsya dal vesny / V veyani razdolnoy / Beloy tishiny" ("Zimnyaya Doroga") [2, c. 119]. In Baltrushaitis' poetry white is never combined with other colours. In his lyrics there is no opposition white-black, typical of other symbolists' poetry. The use of the black colour in Baltrushaitis' artistic world appears to be rare.

Conclusions and prospects of further investigation. The analysis of Baltrushaitis' artistic world shows, that poet 's philosophic and aesthetic views influenced the peculiarities of the colour paradigm, which proves to be versatile. It is shown that the blue colour is considered to be major in Baltrushaitis' colour palette. It is proved that the perception of the blue colour differs in early and late Baltrushaitis' poems. 
The image of blueness develops in a circular way. The images of blueness-eternity and blueness-truth appear to be initial in poet's image system.

The use of the azure colour is influenced by poet's specific outlook and religious tradition. The image of azure appears to be mobile and fluid. In early Baltrushaitis' poetry azure is associated with joyful youth, in later poems the azure is the attribute of the unearthly world and the characteristic of creativity act. It is shown that in early Baltrushaitis poems the white colour is used for creating images of nature. In late Baltrushaitis' the whiteness is associated with the apocalyptical motifs and the theme of expecting the Messiah coming. The image of white corn in poet's artistic world symbolizes the return to the primary source and the start of a new life cycle.

The further research in this area is to be devoted to the analysis of lexico-semantic expressive means and stylistic devices in Yurgis Baltrushaitis' artistic world in the context of the Russian Symbolist poetry.

\section{References:}

1. Альфонсов В.Н. Слова и краски. Москва : Сов. писатель, 1996. 241 с.

2. Балтрушайтис Ю. Дерево в огне. Вильнюс : Vaga, 1983. 319 с.

3. Бальмонт К.Д. Избранное: Стихотворения; Переводы; Статьи. Москва : Худож.лит., 1983. 750 с.

4. Белый А. Стихотворения. Москва : Книга, 1988.575 с.

5. Блок А.А. Собрание сочинений: в 8 томах. Т. 1. Москва-Ленинград : Гос. изд. худ. лит., 1960. 715 с.

6. Блок А.А. Слова и краски. Москва : Рипол Классик, 2016. 268 с.

7. Брюсов В.Я. Собрание сочинений в семи томах. Москва : Худ. лит., 1973. Т. 1.496 с.

8. Брюсов В.Я. Собрание сочинений в семи томах. Москва : Худ. лит., 1973. Т. 7. 378 с.

9. Гаспаров М.Л. Поэтика «Серебряного века». Русская поэзия Серебряного века. 1890-1917. Антология. Москва : Наука, 1993. С. 178-192.

10. Дауетите В. Юргис Балтрушайтис. Вильнюс : Vega, 1983. 326 с.

11. Кожевникова Н.А. Словоупотребление в русской поэзии начала XX века. Москва : Наука, 1986. 252.

12. Колобаева Л. Русский символизм. Москва : Изд-во МГУ, 2000. 294 с.

13. Мержвинските Б.А. Балтрушайтис и Блок. Тема художника в эстетической концепции младосимволистов. Из истории реализма конца ХІХ - начала ХХ вв. Москва : Изд-во МГУ, 1986. 158 с.

14. Соколова Н.К. Слово в русской лирике XX века. Воронеж : Изд-во Воронежского университета, 1980. $159 \mathrm{c}$.

15. Тух Б. Путеводитель по Серебряному веку. Москва, 2005. 207 с.

16. Ханзен-Лёве А. Русский символизм. Система поэтических мотивов. Санкт-Петербург : Академический проект, 2003. 816 с.

\section{ЩербиНа В. В. КОЛЬОРОВА ПАРАДИГМА ЯК ОСОБЛИВІСТЬ ПОЕТИЧНОГО СВІТУ ЮРГІСА БАЛТРУШАЙТІСА В КОНТЕКСТІ РОСІЙСЬКОЇ СИМВОЛІСТСЬКОЇ ПОЕЗІЇ}

Статтю присвячено аналізу кольорової парадигми у поетичному світі Юргіса Балтрушайтіса. Російські символісти внесли до світової літератури неповторну систему образів та своєрідну кольорову парадигму. Сприйняття кольору відрізнясться у віриах представників старшого та молодшого поколінь символістів та віддзеркалює їх філософські та естетичні погляди.

Мета статті - визначити особливості використання кольорової парадигми у художньому світі Юргіса Балтрушайтіса та окреслити схожість та відмінність у використанні кольорових образів в ліриці Балтрушайтіса та у творчості представників старшого та молодшого поколінь символістів. Згідно з філософськими поглядами поета, людське життя складається із двох процесів, ще повторюються - підйому та спуску. Обидва прочеси є складними, але вони привносять до життя людини зміни та оновлення. Однакові кольорові образи супроводжують ліричного героя та сприяють розвитку теми вічного руху.

Синій колір є одним із найчастотніших у кольоровій парадигмі Ю. Балтрушайтіса. Образи, які будуються на синьому кольорі вирізняються багатством змісту, рухливістю та різноманітністю значень. Аналіз різних періодів творчості Балтрушайтіса показує, як змінюється образ синього кольору та сприйняття його поетом. Образи, побудовані на синьому кольорі, розвиваються по колу. У ранніх віршах використовуються образи синій - істина, синій - молодість, синій - вічність, синій - постійність. У пізніх творах образ синій - істина набуває більш глибокого філософського змісту.

На використання письменником лазурового кольору вплинули його своєрідний світогляд та релігійна традииія. Лазуровий колір у ліриці Балтрушайтіса вбачається рухомим та текучим. У ранніх віршах лазуровий асоціюється із радістю та молодістю, у пізній ліриці лазуровий стає атрибутом неземного світу та властивістю творчого акту.

Показано, щео в ранніх творах Балтрушайтіса білий колір використовується для створення образів природи. У пізніх віршах білий колір асоиіюється з апокаліптичними мотивами та темою очікування на появу Месії. Образ білого зерна в поетичному світі Балтрушайтіса символізує повернення до першоджерела та початок нового життевого ииклу.

Ключові слова: кольорова парадигма, образ, лірика, художній світ. 